\title{
Answering the Challenge of Industrial Revolution 4.0 Through Improved Skills Use of Technology College
}

\author{
Romi Fajar Tanjung \\ Department of Guidance and Counseling, Faculty of Teacher Training and Education, IAIN Batusangkar, Batusangkar, 27217, Indonesia \\ romifajarr@gmail.com \\ ${ }^{*}$ Corresponding Author \\ Whatsapp Number [+62 82389068549]
}

How to Cite: Tanjung, R. F. (2019). Answering the Challenge of Industrial Revolution 4.0 Through Improved Skills Use of Technology College. International Journal for Educational and Vocational Studies, 1(1), 11-14. DOI: https://doi.org/10.29103/ijevs.v1i1.1374

\section{ARTICLE HISTORY}

Received: 18 January 2019

Revised: 28 February 2019

Accepted: 20 April 2019

\section{KEYWORDS}

Industrial Revolution 4.0

Skills Use of Technology

College

\section{ABSTRACT}

The era of the industrial revolution 4.0 requires working effectively and efficiently, all the activities is quick and easy. Skills use of technology is one of learning skills that must be mastered to achieve success in life in the era of industrial revolution 4.0, especially in the academic field for students undertaking study or the study completion. Skills good use of technology will make the students quickly and easily complete the study. This study aims to analyze the importance of skills enhancement technology use in higher education in order to meet the industrial revolution 4.0. The research sample student counseling. Research data analysis using percentage. The research found that the importance of improving the skills of the use of technology in higher education and in general skills of student technology use is not optimal.

This is an open access article under the CC-BY-SA license.

\section{INTRODUCTION}

In education there is the name of the learning process. Learning activities also need goals, voluntary action and effective learning is not just an activity or activities that flowed away (Chuvgunova \&Kostromina, 2017). Awareness of the importance of science will encourage students to learn and help them develop skills (Velzen, 2012).

Accordingly, there are students who carelessly in learning and some have even stayed a five-semester course complete the thesis, but dropped out due to habit and poor study skills. Learning skills, habits and attitudes have been shown to predict the success of a person learned in college (Crede \& Kuncel, 2008).

Students' will be done and done properly if the student has the skills required at the time of her life. The skills course related to the knowledge and skills that must be possessed by a student so that he is able to undergo lectures at universities with success (Conley, 2005). Skills notes, reading, listening, making inferences, presentations, made a good job, time management and concentration are forms of learning skills that need to be mastered (Elliot, Kratochwill, Cook \& Travers, 2000; Smith, 2000; Pan, 2004; Pepe 2012). In addition, learning skills that are also important to master in the era of industrial revolution 4.0 is the skill in the use of technology, where these skills will facilitate the process of academic activities of students
(Darmawan, 2012).

The phenomenon of the field found that most use of the technology used in the negative. Examples of the use of technology as a negative example, used to play games, chat, watch using the internet, it is done to excess. One of the students' attitude or behavior for the worse that is caused by a bad use of technology, so that the academic work neglected for too long due to play the gadget (Kagan, Cak, Ilhan, \& Kandemir, 2010).

The use of technology in a positive way will give a huge impact in the world of education. The use of technology to makelearning material more attractive, so that students understand the material was active in the learning and lectures. Students are not just passive or merely carrying out routine daily lectures without getting the meaning of the lecture which he lived (Thomas \& Gadbois, 2007; Grills, 2017). Positive use of technology will also facilitate the students in completing tasks effectively and efficiently lectures.

Technology is not a foreign thing today. Especially for students who will always be associated with the world of learning technology because everything is now using sophisticated technology. For example, in the manufacture of paper is expected student typing papers, there is no longer the only handwritten in the manufacture of paper. 
Journal reference list must exist, in the quest journal will certainly not be easy if the student does not have the skills to access the journal. So also in the delivery of the paper should be master of making the power point presentation that looks interesting material. The development of information technology is now capable of processing, packaging, and displays, as well as spreading the learning information both in audio, visual, audio visual multimedia even making the learning process more interesting (Darmawan, 2012).

The results also explain that the industrial revolution had a positive impact, such as the economic, political, military, cultural, especially in education (Hamdan, 2018). Good use of technology in the learning process is highly demanded in order to achieve a positive output in terms of the education system and human resources produced so that Indonesian country has made progress.

Table 1. Item Statement of Use of Technology

\section{METHODS}

This research method uses a quantitative approach with quantitative descriptive research. Place of research at the Universitas Negeri Padang (UNP). The study population of students counseling. The research sample 102 people. As the population is relatively homogeneous, the researchers use a sampling technique by using simple random sampling. The instruments used are questionnaires use of technology with seven enclosed statement (can be seen in Table 1). The instrument is equipped with five alternative answers as follows: Very Appropriate (VA), Appropriate (A), Sufficiently Appropriate (SA), Not Appropriate (NA), and Very Not Appropriate (VNA). Analysis of the data using percentages and described. The results were analyzed with the results of research and theories related to the article.

\begin{tabular}{cl}
\hline No. & \multicolumn{1}{c}{ Statement of Use Technology } \\
\hline 1 & I find out the link website of the college journal subscriptions, so can be used in the search for reference \\
2 & I'm looking for articles related to how to make a power point that is attractive to make the audience the spirit of the discussion lectures \\
3 & I download the e-Book to enrich the reading material during lectures \\
4 & I download the journals to enrich the reading material during lectures \\
5 & I use youtube to find materials that facilitate in completing tasks lectures \\
6 & I am using HP android to facilitate the search reference lecturing duties \\
7 & I use social media as a means of discussion to facilitate the task of lectures \\
\hline
\end{tabular}

\section{RESULTS}

Usage data that has been obtained is processed by using Exel. Here's a picture of the use of technology student counseling at Padang State University.

Table 2. Overview of Use of Technology

\begin{tabular}{|c|c|c|c|c|c|c|c|c|c|c|c|c|c|c|}
\hline \multirow{2}{*}{$\begin{array}{l}\text { Choice } \\
\text { Answers }\end{array}$} & \multicolumn{2}{|c|}{ Item 1} & \multicolumn{2}{|c|}{ Item 2} & \multicolumn{2}{|c|}{ Item 3} & \multicolumn{2}{|c|}{ Item 4} & \multicolumn{2}{|c|}{ Item 5} & \multicolumn{2}{|c|}{ Item 6} & \multicolumn{2}{|c|}{ Item 7} \\
\hline & $f$ & $\%$ & $f$ & $\%$ & $f$ & $\%$ & $f$ & $\%$ & $f$ & $\%$ & $f$ & $\%$ & $f$ & $\%$ \\
\hline VA & 1 & 1.0 & 2 & 2.0 & 3 & 2.9 & 2 & 2.0 & 1 & 1.0 & 0 & 0.0 & 0 & 0.0 \\
\hline A & 13 & 12.7 & 17 & 16.7 & 20 & 19.6 & 4 & 3.9 & 19 & 18.6 & 0 & 0.0 & 3 & 2.9 \\
\hline SA & 55 & 53.9 & 39 & 38.2 & 39 & 38.2 & 35 & 34.3 & 44 & 43.1 & 6 & 5.9 & 25 & 24.5 \\
\hline NA & 26 & 25.5 & 33 & 32.4 & 30 & 29.4 & 43 & 42.2 & 29 & 28.4 & 31 & 30.4 & 24 & 23.5 \\
\hline VNA & 7 & 6.9 & 11 & 10.8 & 10 & 9.8 & 18 & 17.6 & 9 & 8.8 & 65 & 63.7 & 50 & 49.0 \\
\hline Total & 102 & 100 & 102 & 100 & 102 & 100 & 102 & 100 & 102 & 100 & 102 & 100 & 102 & 100 \\
\hline
\end{tabular}

The research found that in the item 1, of 120 people, there is one person chose the answer Very Appropriate (VA), 13 Appropriate (A), 55 Sufficiently Appropriate (SA), 26 Not Appropriate (NA), and 7 Very not Appropriate (VNA). Item 2, there are two people choose the answer (VA), 17 (A), 39 (SA), 33 (NA), and 11 (VNA). Item 3, there are three people choose the answer (VA), 20 (A), 39 (SA), 30 (NA), and 10 (VNA). Item 4, there are two people choose the answer (VA), 4 (A), 35 (SA), 43 (NA), and 18 (VNA). Item 5, there is one person choose the answer (VA), 19 (A), 44 (SA), 29 (NA), and 9 (VNA). Item 6 , there are 6 people chose the answer (SA), 31 (NA), 65 (VNA), no person who chose the answer choices (VA) and (A). Item 7, there are 3 people choose the answer (A), 25 (SA), 24 (NA), and 50 (VNA), and no one who chose the answer choices (VA). 
The results found that the percentage of all students in the use of technology in item 6 is not optimal, meaning that all students (100\%), their answer choices falls under the category Appropriate (A). In item 7 there were $97.1 \%$ of students are not yet optimal use of technology, on item 4 as much as $94.1 \%, 86.3 \%$ as much as the item 1, item 2 as much as $81.4 \%, 80.4 \%$ as much as the item 5 , item $377.5 \%$. If sorted by item hardest to easiest as follows items $6,7,4$, $1,2,5$, and 3. For more picture detail can be seen in diagram 1.

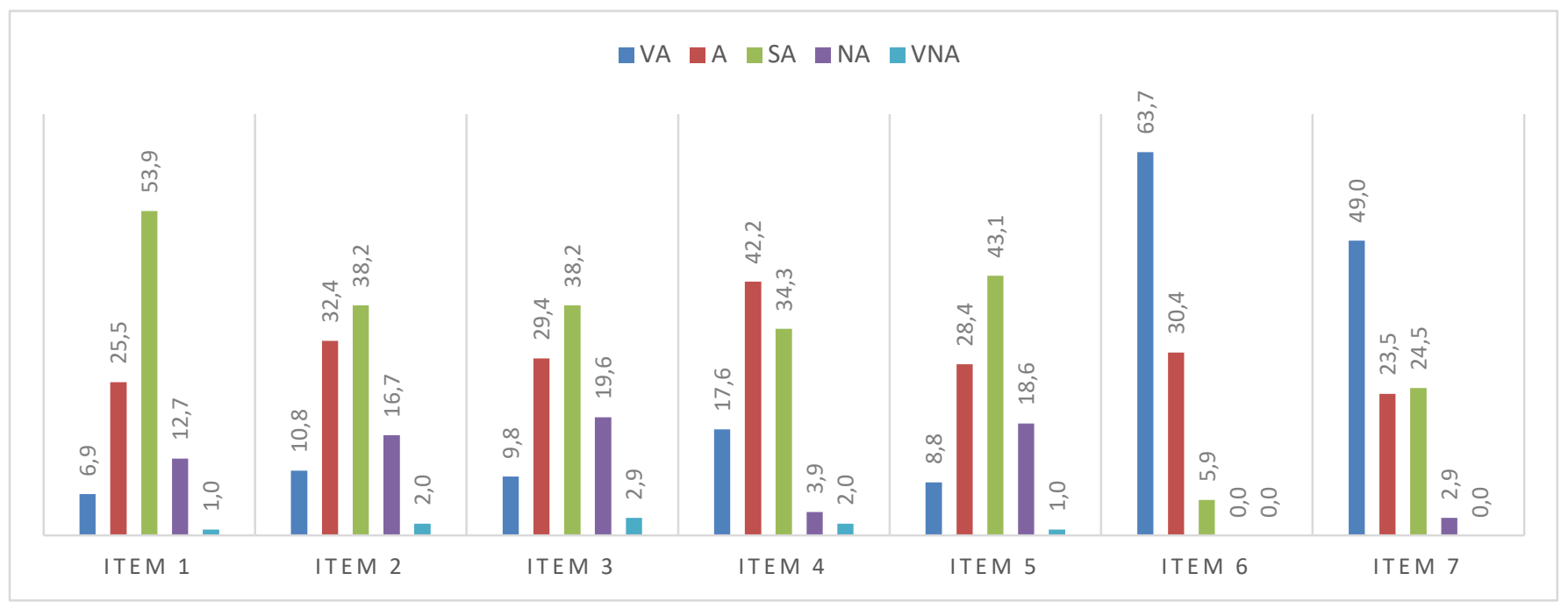

Figure 1. Percentage of Technology Usage per Item

\section{DISCUSSION}

The use of technology in the learning process can not be separated, but need to be used wisely in order not to harm. Following the development of education in the world, should be the purpose of education in this modern world, rather than a dependence on the knowledge and static systems. Likewise, students are expected to use technology to support their success in the academic field. Based on the above results, in general, students still do not have the skills optimal use of technology, it can be seen from the data that shows each item more than 50\% are not using technology optimally in supporting their academic success.

If these countries do not follow the development of the world, then he will be left far behind other countries in education. The use of technology in education during the industrial revolution 4.0 has become a matter of priority (Christen, 2009).

Then the use of technology in higher education is emphasized because education is now oriented towards the development of increasingly sophisticated and modern, as well as one of the goals of education that students master science and technology well. A person will not be left behind when following the current educational developments. But the use of technology will also have a negative impact if their use is not appropriate or misused, for example when the lecture takes place busy student uses her laptop, then this will hinder the learning process in the classroom. Research shows that the use of a laptop that is less precise in the class can also inhibit the ability of students to master the material that is ongoing in the classroom (Fried, 2008;
Hembrooke \& Gay, 2003).

The technology is an effort that is more centered on improving the skills and organization of work, not just machinery and equipment (Uno \& Lamatenggo, 2014). Modern technology is described as a systematization of practical knowledge to increase productivity. Students who lack or do not know the use of technology to better the results of its work are less productive and inefficient. Technology also allows us to complete the learning tasks quickly.

Useful technology to accelerate (stimulate) and trigger (growing) interest in learning (Uno \& Lamatenggo, 2014), resulting in a condition conducive learning (Kurt, 2010), increase student cooperation (Keser, Huseyin, \& Ozdamli, 2011). Good skills in using or accessing the technology will facilitate students in completing tasks lectures mainly in the manufacture of thesis later. So with the convenience gained from the use of technology, will reduce the level of laziness students in completing the task of learning. Technology also makes it easy for educators to access the learning reference (Nelson, Fien, Doabler, \& Clarke, 2016).

The Government explains that in the year 2045 or the golden generation of 2045 wanted to Indonesia creative, where education becomes increasingly important to ensure students have the skills to learn and innovate, skilled use of technology and media information, and be able to work, and survive by using life skills (Arifin, Dardiri \& Hand, 2016). In this case related to a student writing a thesis that 
is inseparable from the use of technology or the Internet. Then the required expertise in accessing journals as reference the scientific literature. The inability of students in using technology is one of the causes of the failure of the study (Rupley, Blair, \& Nichols, 2009).

The above skills are not instinctive but through the learning process. For example, Albert Einstein who can not speak until he was three years old, used to be a dyslexic, which is a disease can not read because of the defect of the brain, he experienced a lot of difficulty when attending school. Thomas Edison several times got a $\mathrm{C}$ for the subjects of physics. New Pablo Picasso managed to finish

\section{CONCLUSION}

Today is the era of the industrial revolution 4.0, where all the activity is quick and easy with the development of increasingly sophisticated technology supported by the wider internet network. These technological advances are expected to be used optimally, precise and positive in the world system of education, especially in higher education, including curriculum, administration, and the learning

\section{REFERENCES}

Conley, D. T. (2005). College Knowledge: What it really takes for students to succeed and what we can do to get them ready. San Fransisco: Jossey-Bass.

Elliot, S. N., Kratochwill, T. R., Cook J. L. \& Travers J. F. (2000). Educational psychology: effective teaching, effective learning. Dubuque: Brown \& Benchmark.

Smith, C. B. (2000). Reading to learn: How to study as you read. Bloomington: ERIC Clearinghouse on Reading, English and Communication. Indiana University.

Pan, D. (2004). The effective student, a guide to learning for the nus student. Singapore: Continental Press Pte Ltd.

Pepe, K. (2012). A research ofthe relationship between study skills of students and their GPA. Procedia Social and Behavioral Sciences, 47, 1048-1057.

Kagan, M., Çak, O., Ilhan, T., \& Kandemir, M. (2010). The explanation of the academic procrastination behaviour of university students with perfectionism, obsessive- compulsive and five factor personality traits. Procedia-Social And Behavioral Sciences, 2(2), 2121-2125.

Thomas, C. R., \& Gadbois, S. A. (2007). Academic self-handicapping: The role of self-concept clarity and students learning strategies. Journal of Educational Psychology, 77(1), 101-119.

Grills, S. (2017). Learning skills workshops supporting first-year courses. Journal Collected Essays on Learning and Teaching, 10, 119-128.

Nelson, N. J., Fien, H., Doabler, C. T., \& Clarke, B. (2016). Considerations for realizing the promise of educational gaming technology. Teaching Exceptional Children, 48(6), 293-300.

Bransford, J. D., Brown, A. L., \& Cocking, R. R. (2000). How people learn: Brain, mind, experience, and school. Washington, DC: National Academy Press.

Rupley, W. H., Blair, T. R., \& Nichols, W. D. (2009). Effective reading instruction for struggling readers: The role of direct/explicit teaching. school, accompanied by his father sitting beside him during the learning process (Aleinikof, 2002). Every child and every person can become better. History shows that every person has the opportunity to become better if you want to try and learn (Aleinikof, 2002).

The research found that the use of appropriate technology and can positively improve the performance of educators and student learning outcomes (Bransford, Brown, \& Cocking, 2000). In addition, skills are also very important to use technology to support their careers forward to compete in the digital age (Nelson, Fien, Doabler, $\&$ Clarke, 2016).

process. Students who have graduated and has a good technology skills in the era of the industrial revolution 4.0 will be able to compete in the world of work and have a clear career later. However, the research found that in general the students not using technology optimally in supporting the success of their academics.

Reading \& Writing Quarterly, 25(2), 125-138.

Chuvgunova, O. \& Kostromina, S. (2017). Planning as a learning skill of students. Procedia Social and Behavioral Sciences, 217, 132-138.

Velzen, V. J. H. (2012). Teaching metacognitive knowledge and developing expertise. Journal Teachers and Teaching, 18(3), 365-380.

Crede, M. \& Kuncel. N. R. (2008). Study habits, skills, and attitudes: The third pillar supporting collegiate academic performance. Journal Perspectives on Psychological Science, 3(6), 425-53.

Darmawan, D. (2012). Inovasi pendidikan pendekatan praktik teknologi multimedia dan pembelajaran online. Bandung: Remaja Rosdakarya.

Fried C. B. (2008). In class laptop use and its effects on student learning. Journal Computers \& Education, 50(3), 906-914.

Hembrooke. H. \& Gay. G. (2003). The laptop and the lecture: The effects of multitasking in learning environments. Journal of Computing in Higher Education, 15(1), 46-64.

Uno, H. B \& Lamatenggo, N. (2014). Teknologi komunikasi \& informasi pembelajaran. Jakarta: Bumi Aksara.

Arifin, M., Dardiri, A. \& Handayani, A. N. (2016). Hubungan kemampuan penyesuaian diri dan pola berpikir dengan kemandirian belajar serta dampaknya pada prestasi akademik mahasiswa. Jurnal Pendidikan, 1(10), 1943-1951.

Aleinikov, A. G. (2012). Mega creativity five steps to thinking like a genius. Terjemahan Gunardi. Yogyakarta: Imperium.

Christen, A. (2009). Transforming the classroom for collaborative learning in the 21 st century. Techniques: Connecting Education and Careers, 84(1), 28-31.

Keser, H., Uzunboylu, H., \& Ozdamli, F. (2012). The trends in technology supported collaborative learning studies in 21 st century. World Journal On Educational Technology, 3(2), 103-119.

Kurt, S. (2010). Technology use in elementary education in Turkey: A case study. New Horizons in Education, 58(1), 65-76. 